\title{
Inocybe caprimulgi and I. lacunarum, two new nodulose-spored species from Fennoscandia
}

\author{
JUKKA VAURAS and ELLEN LARSSON
}

\begin{abstract}
VAURAS, J. \& LARSSON, E. 2015 (2016): Inocybe caprimulgi and I. lacunarum, two new nodulose-spored species from Fennoscandia - Karstenia 55: 1-18. HELSINKI. ISSN 0453-3402.
\end{abstract}

Two nodulose-spored species, belonging to section Marginatae, are described from Fennoscandia. Inocybe caprimulgi grows on sandy soils from the hemiboreal zone to lowalpine zone. I. lacunarum appears often in moist depressions, in the hemiboreal and southern boreal zones. I. substellata is recorded for first time from Sweden, Norway and Finland, and I. krieglsteineri from Sweden.

Key words: Inocybe, Agaricales, taxonomy, molecular systematics

Jukka Vauras, Biological Collections of Abo Akademi University, Herbarium, FI-20014 University of Turku, Finland; e-mail: jukvau@utu.fi

Ellen Larsson, University of Gothenburg, Department of Biological and Environmental Sciences, Box 461, SE-40530 Göteborg, Sweden; e-mail: ellen.larsson@bioenv.gu.se

\section{Introduction}

The access to molecular data has greatly increased our knowledge and understanding of the species diversity of fungi (Kõljalg et al. 2013). Sequence analyses have become a powerful tool and an aid in the evaluation of morphological characters used to determine and diagnose species. In addition, ecology and distribution ranges of species can be more properly defined. This has especially been valuable for groups with morphological variable characters and seemingly broad ecology as often encountered within Inocybe (Fr.) Fr. (Cripps et al. 2010, Kokkonen \& Vauras 2012, Larsson et al. 2014, Esteve-Raventós et al. 2015). By using ITS sequence data generated from type specimens comparisons can be made with data from recently collected material and the names be nailed down and species complexes sorted out. This has also facilitated the recognition of new species (Larsson et al. 2014, Esteve-Raventós et al. 2015).
Inocybe section Marginatae Kühner (Kühner 1933) is known to hold several species complexes where names have been very differently interpreted (Esteve-Raventós et al. 2015). In the present study we compare the morphology and sequence data of specimens collected from boreal ecosystems and for which it has been hard to find proper names based on morphology alone, with morphologically similar species including several types. With the support from phylogenetic analyses of ITS and LSU sequence data we here describe two new species to science in section Marginatae. In addition, two new species were recognized as new to Fennoscandia.

\section{Material and methods}

The main portion of the specimens was collected by the authors in Northern Europe (Fennoscandia). Ad- 
ditional material was included from $\mathrm{GB}, \mathrm{H}$, OULU, S, TUR, TUR-A and UPS. Selected collections were photographed in situ. Macroscopical features were noted and cross-sections drawn from some fresh fruit bodies. The colour codes refer to Cailleux (1981) or Küppers (1981). Microscopical characters were measured and drawn from dried material mounted in $10 \% \mathrm{NH}_{4} \mathrm{OH}$ solution and at $1000 \times$ magnifications following the methodology described in Vauras \& Kokkonen (2009). The acronyms of the herbaria follow those used by Holmgren et al. (1990). When two or more herbaria are cited, the prime material is deposited in the first cited.

Thirty specimens of Inocybe section Marginatae from Northern Europe were targeted for sequencing in this study, including the holotype of I. substellata Kühner and a paratype of I. populea Takah. Kobay. \& Courtec. The sequenced specimens are indicated with asterisk in lists of specimens examined. In addition ITS and LSU sequence data from previous studies on Inocybe were included (Ryberg et al. 2010, Esteve-Raventós et al. 2015).

Sequences from the complete ITS region and about 1400 base pairs (bp) of the 5'end of the LSU nuclear ribosomal DNA were generated for the study. DNA extractions, PCR reactions, and sequencing were performed as described in Larsson \& Örstadius (2008). The type specimens were extracted using a modified CTAB method and PCR and sequencing followed protocols described in Larsson \& Jacobsson (2004). Primers used to amplify the complete ITS region and the 5 ' end of the LSU region were ITS1F (Gardes \& Bruns 1993) and LR21, LR0R, and LR7 (Hopple \& Vilgalys 1999). Primers used for sequencing were ITS1, ITS4 (White et al. 1990), Ctb6 (http://plantbio.berkeley.edu/ bruns/) and Lr5 (Hopple \& Vilgalys 1999). Sequences were edited and assembled using Sequencher 5.1 (Gene Codes, Ann Arbor, Michigan). Sequences generated for this study have been deposited in GenBank under the accession numbers (KT958904KT958933).

Alignment was performed using the L-INS-i strategy as implemented in MAFFT v. 7.017 (Katoh \& Standley 2013). The alignment was adjusted manually using the data editor in PAUP* 4.0b12 (Swofford 2003). For inferring phylogenetic relationships among species heuristic searches for the most parsimonious trees were performed using PAUP* (Swofford 2003). All transformations were considered unordered and equally weighted. Variable regions with ambiguous alignment were excluded and gaps were treated as missing data. Heuristic searches with 1,000 random-addition sequence replicates and TBR branch swapping were performed, saving at most 25 trees in each replicate. Relative robustness of clades was assessed by the bootstrap method using 1,000 heuristic search replicates with 100 random taxon addition sequence replicates and TBR branch swapping, the latter saving at most 25 trees in each replicate. In addition a Bayesian analysis was carried out in MrBayes 3.0 (Ronquist \& Huelsenbeck 2003), with a best-fit model of nucleotide evolution supplied by MrModeltest 2.2 (Nylander 2004). ). As suggested by MrModeltest, the nucleotide evolution model HKY $+\mathrm{G}$ was used for the ITS1 spacer; $\mathrm{SYM}+1$ was used for the $5.8 \mathrm{~S}$ gene; $\mathrm{HKY}+\mathrm{G}$ was used for the ITS2 spacer; and GTR $+\mathrm{I}+\mathrm{G}$ were used for the LSU in the Bayesian analysis. The MCMC analysis converged well in advance of the burn-in threshold and chain mixing was found to be satisfactory, as assessed by using Tracer v1.5 (Drummond et al. 2012). Eight defaultsetting Metropolis-Coupled Markov Chain Monte Carlo (MCMCMC) chains were run for 10 million generations with trees sampled every 5,000 generations and an initial burn-in of 1000 trees. After discarding the trees prior to the burn-in threshold a 50\% majority-rule consensus phylogram was computed from the remaining trees.

\section{Results}

Sequences were edited and assembled using Sequencher 5.1 (Gene Codes, Ann Arbor, Michigan). The aligned complete dataset consisted of 47 sequences and 2254 characters. After exclusion of ambiguous regions mainly from the ITS region, 2217 characters remained for the analysis. Of these, 1478 were constant, 63 were variable but parsimony uninformative, and $478(22 \%)$ were parsimony informative. The maximum parsimony analysis yielded 24900 equally most parsimonious trees (length $=960$ steps, $\mathrm{CI}=0.7521$, and $\mathrm{RI}=0.9140$ ). One of the trees is presented as a phylogram in Fig. 1. The bootstrap analysis recovered 10 terminal clades and a single branch as monophyletic and with strong bootstrap support, corresponding to Inocybe hirculus Vauras, I. caprimulgi sp. nov., I. substellata, I. salicis Kühner, I. lacunarum sp. nov., I. diabolica Vauras, I. krieglsteineri Fernández Sas., I. decemgibbosa (Kühner) Vauras, I. grammata Quél., I. napipes J.E. Lange, and a single branch, I. populea. In the Bayesian analysis the same 10 clades as in the MP analysis were recovered as monophyletic with strong support, a Bayesian posterior probability (BPP) of 1.0 (Fig. 1). The Bayesian tree topology was identical to the tree presented in Fig. 1.

\section{Taxonomy}

Inocybe caprimulgi Vauras \& E. Larss., sp. nova - Figs. $2-3,6 a-b, 7-8$

\section{MycoBank no.: MB 815078}

Diagnosis: Medium-sized species with stipe totally pruinose and spores angular to nodulose, measuring (7.5-)8.1-10.4(-11.2) × (5.3-)5.77.5(-7.9) $\mu \mathrm{m}$, and resembling I. krieglsteineri. Macroscopically not yellowish-colored but more 


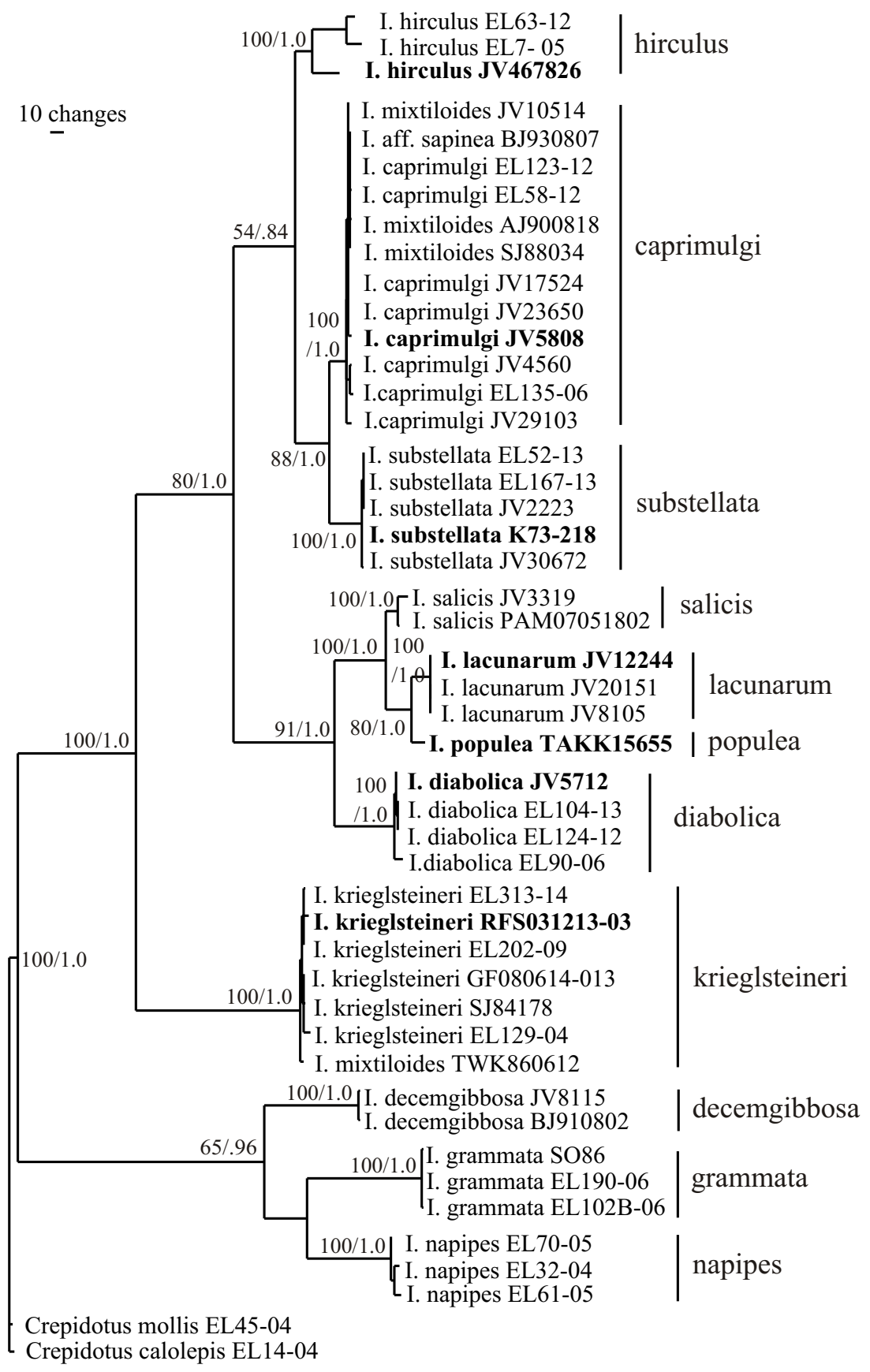

Fig. 1. One of the equally most parsimonious trees from the phylogenetic analysis based on nuclear rDNA ITS and partial LSU sequences. Parsimony bootstrap values and Bayesian posterior probabilities are indicated on branches. Clades discussed in the text are indicated with bars and species epithets. Sequences originating from holotype or isotope specimens, and the paratype of I. populea, are marked in bold. Abbreviations for collector numbers: EL=Ellen Larsson, $\mathrm{JV}=$ Jukka Vauras, BJ = Bo Jansson, SJ = Stig Jacobsson, AJ = Anders Janols, TWK = Thomas Kuyper, K = Robert Kühner, PAM = Pierre-Arthur Moreau, TAKK = Takahito Kobayashi, RFS = Roberto Fernández Sasia, GF = Giuliano Ferisin, $\mathrm{SO}=$ Sören Olsen. 


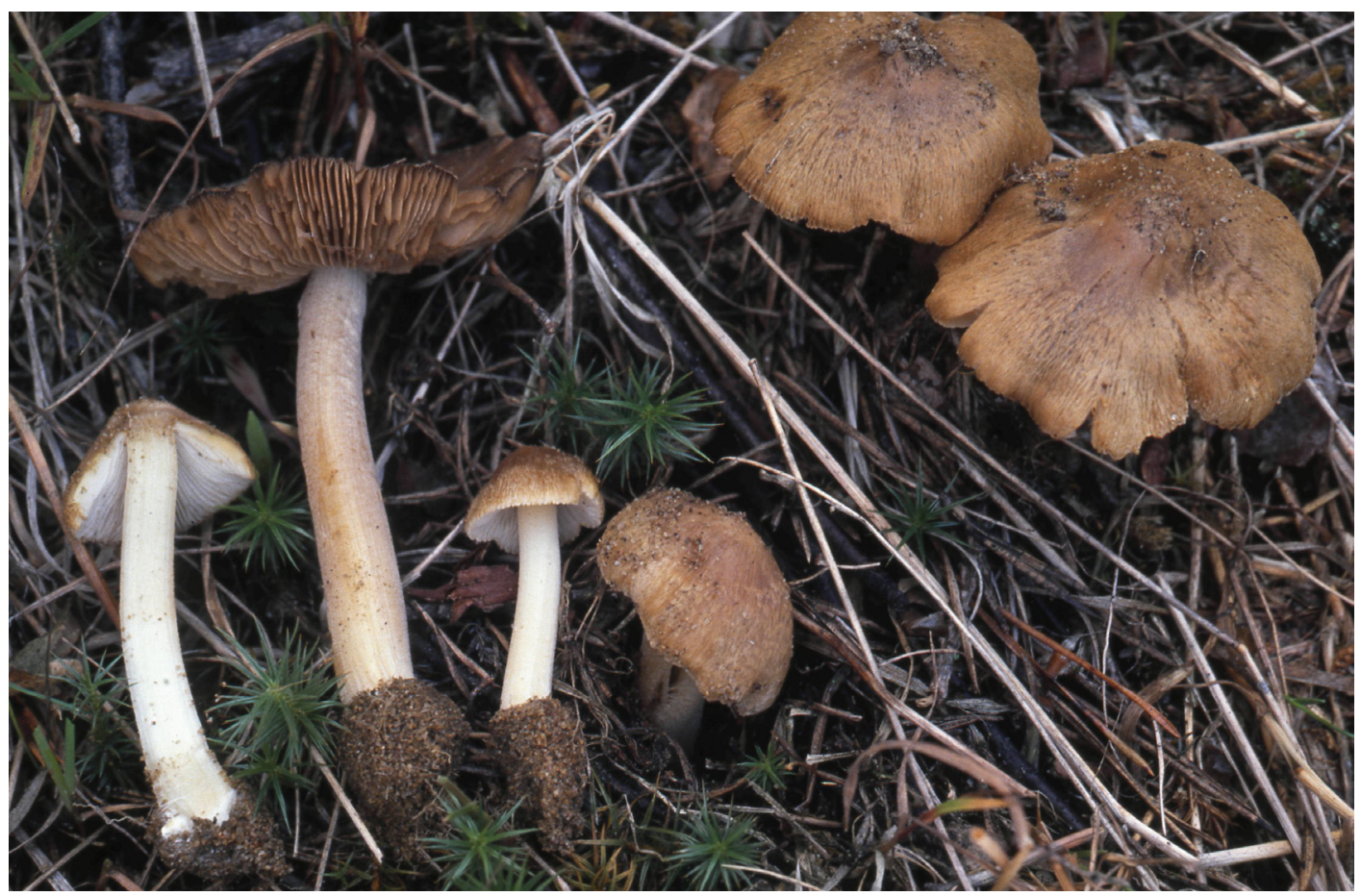

Fig. 2. Inocybe caprimulgi. Vauras $4560 F$. Fairly young fruiting bodies in southern boreal zone. - Photo: J. Vauras.

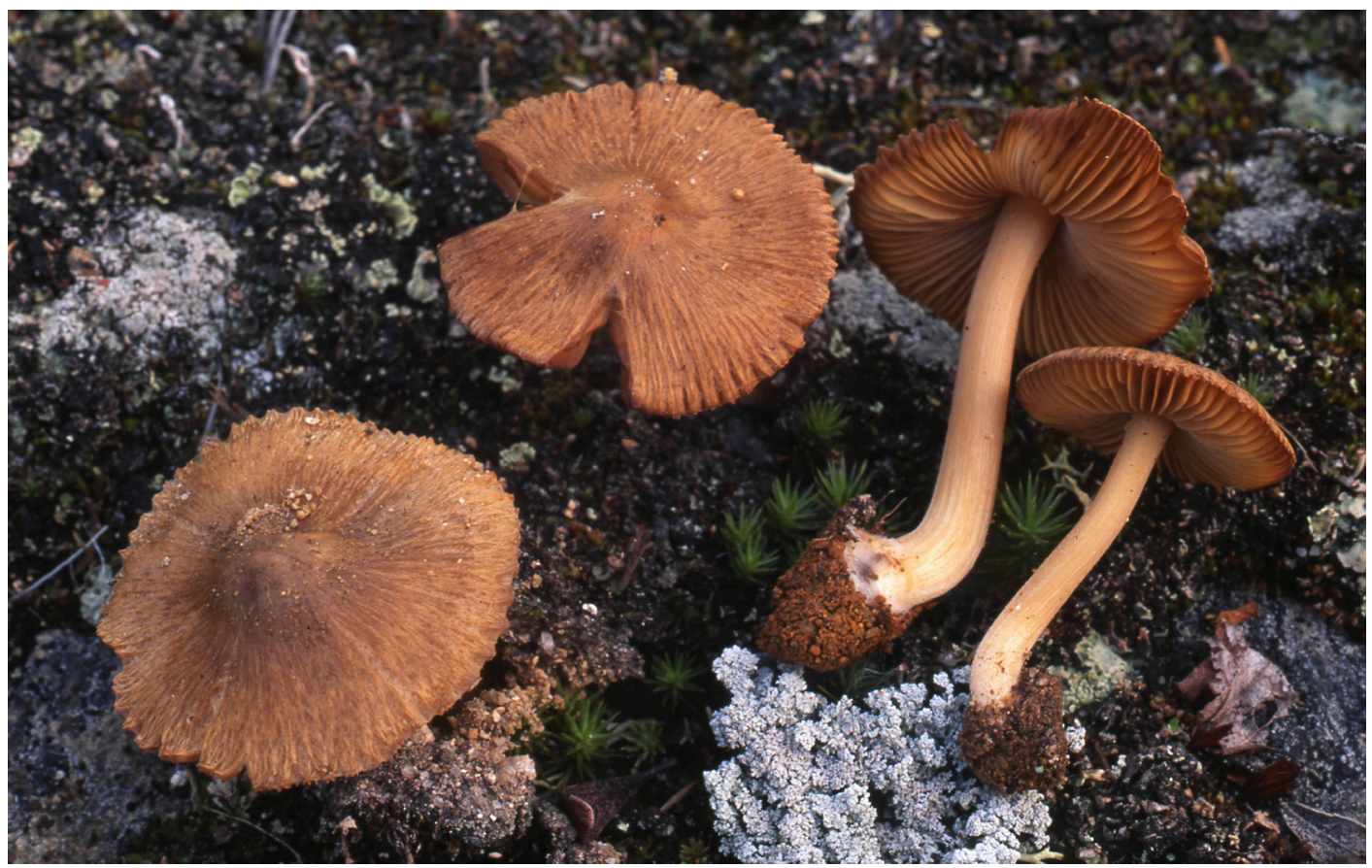

Fig. 3. Inocybe caprimulgi. Vauras $10514 F$. Fruit bodies in northern boreal zone. - Photo: J. Vauras. 
grey-brown, microscopically having narrower spores and on average shorter and broader cystidia often with rounded bases, compared with I. krieglsteineri. Boreal species with habitat on sandy soils, with Pinus sylvestris and Betula. According to the sequence analyses not as closely related with $I$. krieglsteineri as I. substellata.

Typus: Finland. Perä-Pohjanmaa. Rovaniemi, Pahtaja, ca 200 m SSE from Lapin Metsäkoulu, on bank of the main road, dry heath forest with Pinus sylvestris, with young Betula sprouts on the bank, on fine sand, alt. ca $82 \mathrm{~m}$, grid $27^{\circ} \mathrm{E}$ : 73715:34372, 22.VIII.1991 Vauras $5808 \mathrm{~F}$ (TUR-A 176158 - holotypus; GB, H - isotypi, GenBank No. KT958924).

Etymology: caprimulgi (gen.), named after the bird nightjar, Caprimulgus europaeus, living in dry pine forests.

Pileus $2.0-5.0 \mathrm{~cm}$ in diam, when young conicoconvex to convex, with slightly inflexed margin, then expanding, slightly umbonate, margin often undulate; first grey, dirty yellow-greyish brown $(67 \mathrm{~N})$, yellow-brown (Y40M30C10, 91L-M), later brown (33R), dirty brown to dark brown (75S), at center subtomentose, sometimes with whitish velipellis, towards margin coarsely fibrillose, margin somewhat breaking up. Lamellae fairly crowded, mostly narrow, but up to 5 mm wide, narrowly adnate to free, whitish, then grey $(91 \mathrm{~K})$, brownish grey (S30Y30M10, 70M, 90L), then grey-brown, later brown (49P), edge concolorous to pale. Stipe 3.5-6.2 × 0.4-1.0 $\mathrm{cm}$, equal to slightly clavate, base often marginately bulbous, up to $1.1 \mathrm{~cm}$ wide; first white to slightly yellowish, then pale brownish grey (70M), brownish yellow (65-67N) to pale brown (50M), base white; totally white-pruinose, longitudinally striate. Context in pileus thin, whitish, partly pale brown to slightly yellow-brown, in stipe whitish to pale yellowish, yellow-brown to pale brownish yellow, shiny. Smell weakly acidulous or indistinct. Color of exsiccatae fairly dark, pileus mostly grey-brown to dark brown, sometimes blackish, lamellae pale brown to dark brown, stipe pale grey, dark brown to blackish, flesh grey, brown to blackish, but in bulb pale, sometimes whitish. Spores (7.5-)8.19.2-10.4(-11.2) × (5.3-)5.7-6.5-7.5(-7.9) $\mu \mathrm{m}$, range of mean values $8.7-9.6 \times 6.0-6.9 \mu \mathrm{m}, \mathrm{Q}$
$=(1.25-) 1.3-1.42-1.55(-1.65)$, range of mean $\mathrm{Q}$-values $1.36-1.46(\mathrm{n}=140$, from 7 collections); oblong, angular, with about 7-8 rather prominent, rounded nodules, rather pale yellow brown. Basidia 23-29-34(-37) × 8-10-11 $\mu \mathrm{m}$, clavate, 4-spored ( $\mathrm{n}=57$, from 6 collections). Pleurocystidia frequent, (45-)48-59-71(-78) $\times$ (15-)16-19-22(-23) $\mu \mathrm{m}(\mathrm{n}=64$, from 7 collections), utrtiform to fusiform, often with rounded base, thick-walled, with up to $4.5 \mu \mathrm{m}$ thick, pale yellow wall, often with abundant crystals, in some collections crystals scarce. Cheilocystidia fairly similar to pleurocystidia but shorter and more variable, $32-50-68 \times 14-20-28 \mu \mathrm{m}(\mathrm{n}=$ 47 , from 3 collections), often with yellow-brown contents and with rounded base; paracystidia abundant, clavate, pyriform to oval, 13-20-28 $\times$ 6-9-14 $\mu \mathrm{m}(\mathrm{n}=30$, from 4 collections). Caulocystidia descending to base of stipe, at apex 48-65-99 × 14-18-27 $\mu \mathrm{m}(\mathrm{n}=58$, from 4 collections), fairly similar to cheilo- and pleurocystidia but more variable, often with rounded base, some with brownish contents; cauloparacystidia at stipe apex clavate, oval or pyriform, 14-21-28 $\times 5-12-16 \mu \mathrm{m},(\mathrm{n}=18$, from 4 collections $)$, at stipe base more hyphoid.

Specimens examined: FINLAND. VarsinaisSuomi. Salo, Kisko, Lakianummi, 20.IX.2012 Vauras 29354 (TUR-A); Perniö, Tuohittu, 4.VIII.2015 Vauras 31010 (TUR-A). Sauvo, Kivimäki, 17.VII.1998 Kytövuori 98-081a $(\mathrm{H})$. Turku, near airport, 1.VIII.1998 Issakainen (TUR-A), 22.VIII.1998 Issakainen \& Vauras 14070F, 14071 (TUR-A); Paattinen, Lavamäki, 9.IX.1990 Kulmala (TUR-A); Uusimaa. Hanko, Lappohja, 10.IX.1964 Eriksson (3 coll. TUR), 1.IX.1965 Eriksson (TUR). Satakunta. Harjavalta, IX.1970 Eriksson (OULU). Jämijärvi, Aviation Centre, 17.IX.1967 Eriksson. Karvia, Kantti, 25.VII.1990 Vauras 4504 (TUR-A). Loimaa, Alastaro, Virttaankangas, 21.IX.2001 Vauras 17995 (TUR-A), 2.IX.2004 Vauras 21923 (TUR-A), 23.IX.2005 Vauras 23650* (TUR-A, GB), 1.VIII.2007 Vauras 25000, 25003, 25007 (TUR-A), Etelä-Häme. Joutsa, Leivonmäki, Selänpohja, 15.VIII.1993 Kytövuori 93-155 (H), 22.VIII.1993 Kytövuori 93-461 (H), 10.VIII.1996 Kytövuori 96-458 (H). Ruovesi, Siikakangas, 14.IX.1999 Vauras 15515 (TUR-A). Pohjois-Häme. Muurame, Suuruskangas, 7.VIII.1990 Vauras 4560F* 
(TUR-A, GB, L). Kyyjärvi, Oikari, 1.IX.1999 Vauras 15076 (TUR-A). Pohjois-Savo. Kuopio, Nilsiä, Palokangas, 15.VIII.2008 Vauras 26101 (TUR-A); Vehmersalmi, Jänissalo, 5.VIII.2003 Vauras 19798 (TUR-A). Siilinjärvi, Harjamäki, 2.IX.1994 Vauras 9442 (TUR-A). Pieksämäki, Virtasalmi, church yard, 16.IX.2004 Vauras 22144 (TUR-A). Pohjois-Karjala. Ilomantsi, Koivusuo Strict Nature Reserve, 7.IX.1985 Vauras $1988 F$ (TUR-A, L). Nurmes, Puu-Nurmes, 13.VIII.2003 Kokkonen 142/03 (TUR); Raesärkät, 23.VIII.1996 Ruotsalainen \& Vauras 11500 (TUR-A), 23.IX.2003 Kokkonen \& Vauras 20930 (TUR-A). Kainuu. Paltamo, Saukkovaara, 24.VIII.2011 Vauras 28358 (TUR-A); Tololanmäki, 16.VIII.2014 Vauras 30620, 30621 (TUR-A). Ristijärvi, Koljatinvaara, 17.VIII.2014 Vauras 30632 (TUR-A). Suomussalmi, Petäjävaara, 27.VIII.2011 Vauras 28402, 28415 (TUR-A). Oulun Pohjanmaa. Pudasjärvi, Rytkynharju, 2.VIII.2013 Lahti 25/13F (TUR). Koillismaa. Kuusamo, Iivaara, 24.VIII.1992 Vauras 7020 (TUR-A), 31.VIII.1996 Vauras 11694 (TUR-A); Jäkäläniemi, 18.VIII.2008 Vauras 26161 (TUR-A); near Jäkälävaara, 26.VIII.2005 Vauras 23177 (TURA); near Kiutaköngäs, 22.VIII.1983 Ohenoja (OULU), 26.VIII.2015 Bandini \& Vauras 31140 (TUR-A); Nurmisaarenniemi 20.VIII.2015 Oertel, Bandini \& Vauras 31111 (TUR-A); near Research Station, 24.VIII.1974 Tuomikoski (H), 21.VIII.1992 Vauras 6935 (TUR-A), 3.IX.1996 Vauras 11790 (TUR-A); near Uopajanpuro, 16.VIII.2009 Vauras 26956 (TUR-A). Posio, Riisitunturi National Park, 27.VIII.2005 Vauras 23222 (TUR-A), 29.VIII.2011 Vauras 28439 (TUR-A). Salla, near Mooseksenkuru, 24.VIII.2007 Vauras 24953; Naruska, 7.IX.1994 Väre (OULU); Oulanka, 20.VIII.2008 Vauras 26169 (TUR-A). Perä-Pohjamaa. Rovaniemi, Jaatilanvaara, 11.IX.1999 Vauras 15076 (TURA); Lautavaara, 24.VIII.2007 Kokkonen \& Vauras 24969 (TUR-A); Pahtaja, 20.VIII.1990 Vauras 4880 (TUR-A), 22.VIII.1990 Vauras 4899 (TUR-A), 22.VIII.1991 Vauras 5808F* (holotype, isotypes), 19.VIII.1992 Vauras $6871 F$ (TUR-A); Tavivaara, 20.VIII.1991 Vauras 5798 (TUR-A), 23.VIII.1991 Vauras 5816 (TUR-A), 20.VIII.1992 Vauras 6905 (TUR-A). Tornio, Arpela, Korkiamaa, 21.VIII.2004 Vauras 21748 (TUR-A). Kittilän Lappi. Kolari, Kolarinsaari, 26.VIII.2014 Della Rovere (TUR-A). Sompion
Lappi. Pelkosenniemi, Alaperä, 23.VIII.1994 Nummela-Salo \& Salo (OULU); near Rykimäselkä, 28.VIII.2008 Vauras 26377, 26400 (TURA); Suvanto, 2.IX.1991 Ohenoja (OULU), 28.VIII.2008 Vauras 26395 (TUR-A). Savukoski, Sokli, 21.VIII.2008 Vauras 26216 (TUR-A). Sodankylä, Luosto, 27.VIII.2008 Vauras 26359 (TUR-A). Enontekiön Lappi. Enontekiö, Järämä, 19.VIII.2014 Vauras 30647 (TUR-A); Kuttanen, 31.VIII.2013 Vauras 30090 (TUR-A). Inarin Lappi. Inari. Kaamanen, 17.VIII.1961 Kallio (TUR). Utsjoki, Karigasniemi, Ailigas, 16.VIII.1963 Kankainen (TUR), Luomushjoki, 17.VIII.1963 Kankainen (TUR).; Kenesjärvi N, 7.VIII.1962 Kallio (TUR); Kevo, 16.VIII.1962 Kallio (TUR), 21.VIII.1962 Kallio (TUR), 17.VIII.1964 Kankainen (TUR), 15.VIII.1995 Vauras 10428 (TUR-A), 18.VIII.1995 Vauras $10514 F^{*}$ (TUR-A, WTU), Heinonen 421-95F (TUR). NORWAY. Sør-Trøndelag. Oppland, Dovrefjell National Park, near Kongsvoll, 18.VIII.2012 Vauras 29044F (TUR-A, O), Larsson $58-12 *(\mathrm{~GB}), 22$.VIII.2012 Larsson 123-12* (GB). Finnmark. Tana, Rastigaisa, 18.VIII.1995 Huhtinen (TUR, O). SWEDEN. Småland. Femsjö, Slättagärdet, 10.IX.1940 Lundell 3472 (UPS). Värmland. Dalby, V. Grobackberget, 7.VIII.1993 Jansson* (GB). Dalarna. Gagnef, Backamon, 18.VIII.1990 Janols* (GB). Härjedalen. Tännäs, Svansjökläppen, 19.VIII.2006 Larsson 135-06* (GB). Jämtland. Undersåker, Renfjället, 25.VIII.2001 Vauras 17524F* (TUR-A); Trillevallen, 20.VIII.1988 Jacobsson 88034* (GB, TUR-A). Ångermanland. Graninge, Åkroken W, 28.VIII.1997 Kytövuori 97378 (H); Viksmon, 6.IX.1997 Kytövuori 97-812 (H). Pite lappmark. Arvidsjaur, near Avaviken, 24.VIII.2012 Vauras 29103* (TUR-A, GB).

Specimens of Inocybe krieglsteineri examined for comparison: FRANCE. Île-de-France. Forêt Rambouillet, Pinus sylvestris, Betula, 24.VI.2012 Kokkonen 5/12 (TUR-A). GERMANY. Rhineland-Palatinate. Mehlingen, Mehlinger Heide, Pinus sylvestris, Quercus robur, 25.X.2014 Bandini (TUR-A). Rheinböllen, Hirtenborn, Helianthemum, Quercus robur,11.XI.2011 Bandini (TUR-A). THE NETHERLANDS. Drenthe. Gieten - Rolde, Quercus robur, 12.VI.1986 Kuyper* (TUR-A). Gelderland. Rheden, Heuven, Quercus robur, 6.IX.1986 Kuyper 2698 (TUR-A). SLOVAKIA. 


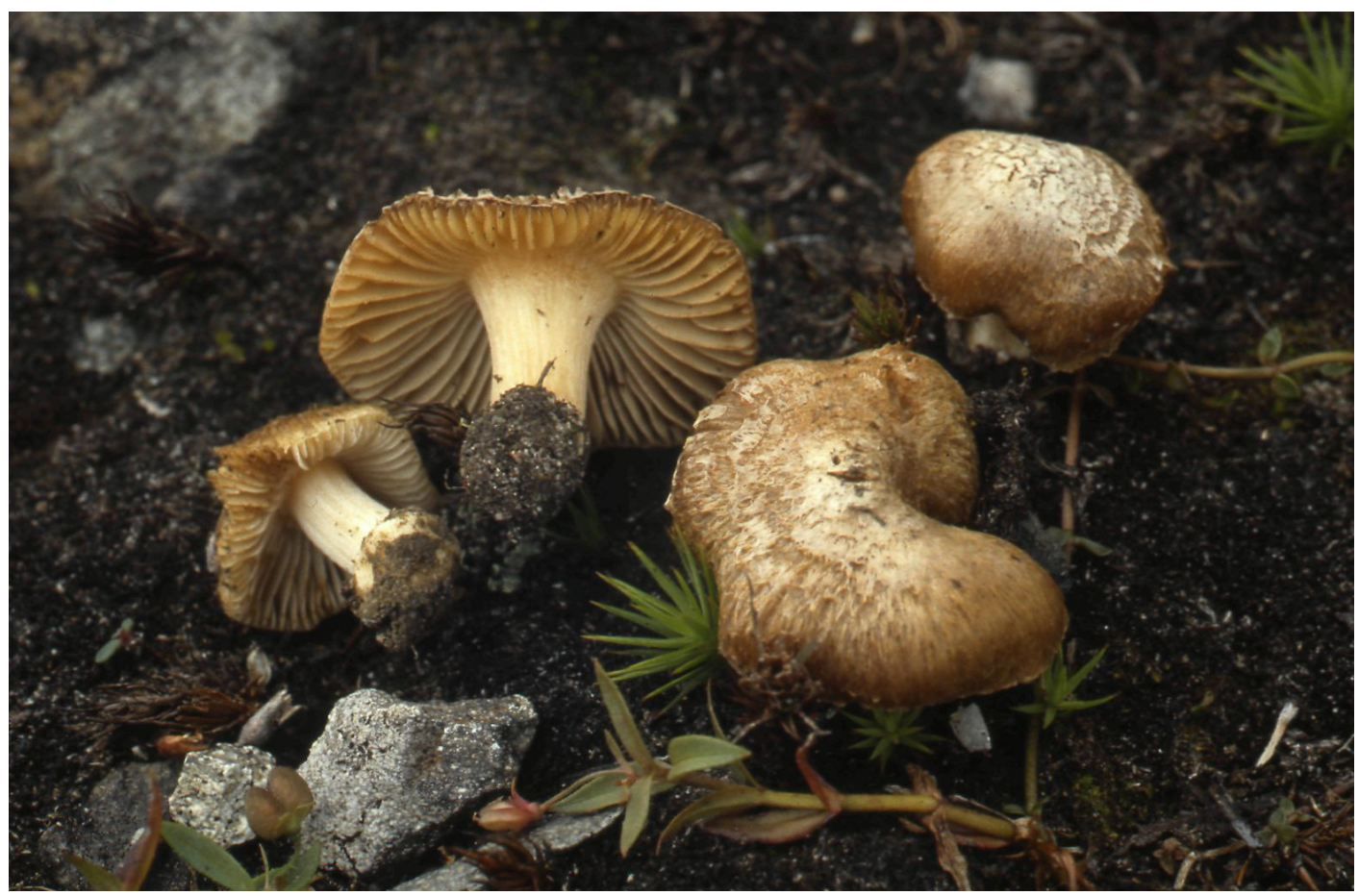

Fig. 4. Inocybe substellata, Vauras 2223F. - Photo: J. Vauras.

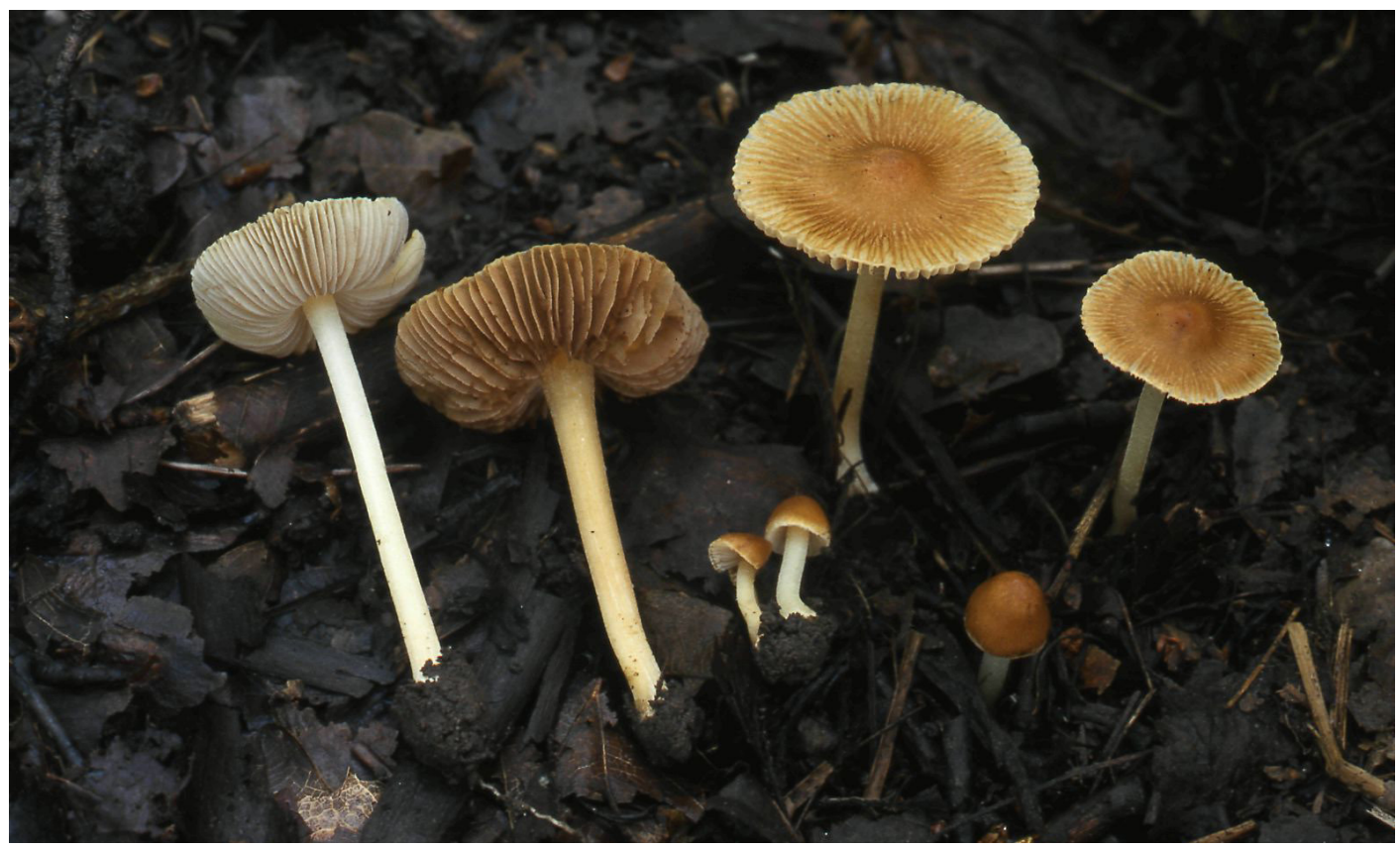

Fig. 5. Inocybe lacunarum, holotype. - Photo: J. Vauras. 

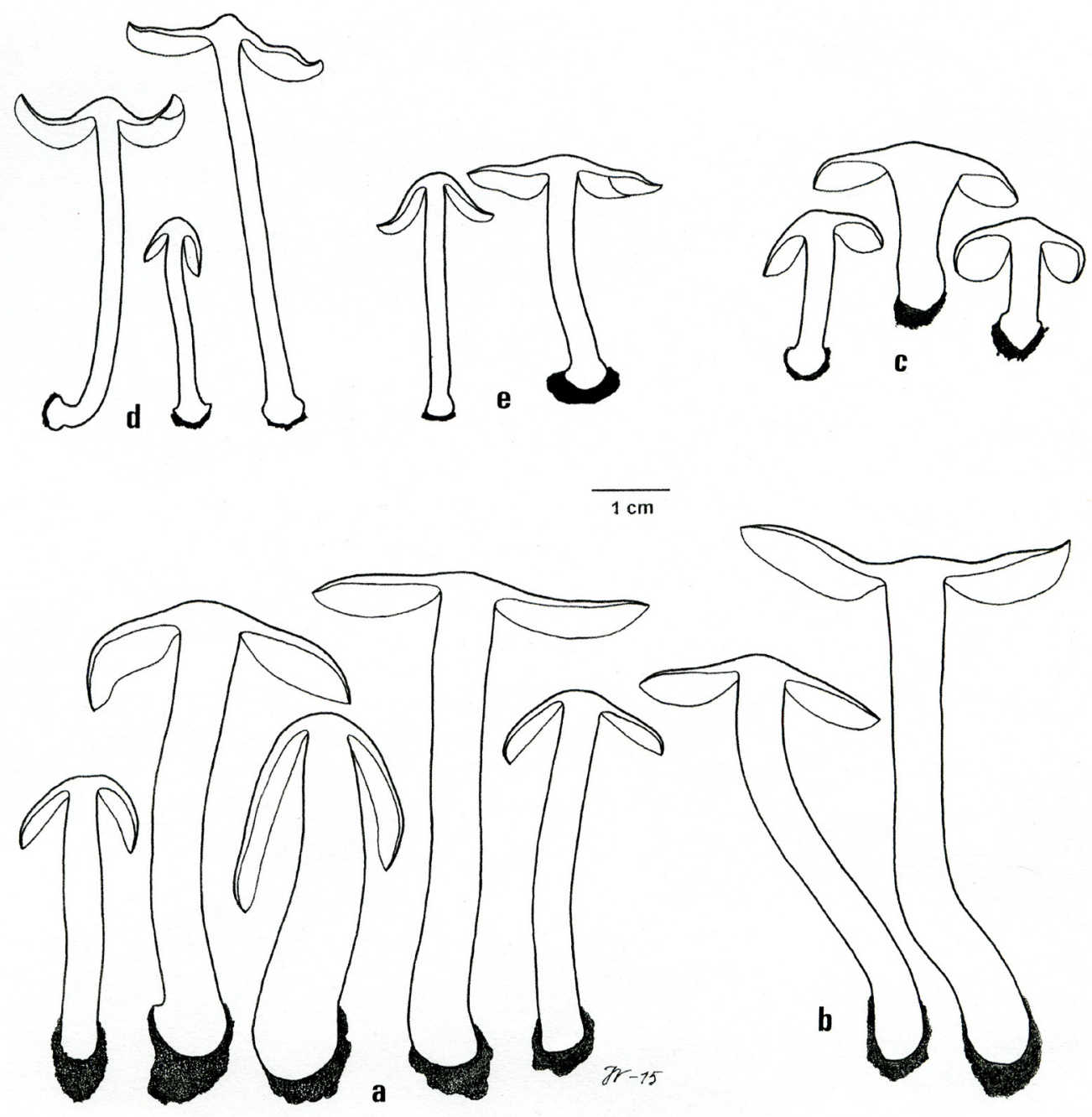

Fig. 6. Cross sections of fruiting bodies. - Inocybe caprimulgi, a) Vauras 4560F, b) holotype. - c) Inocybe substellata, Vauras 2223F. - Inocybe lacunarum, d) Vauras 8105F, e) Vauras 7093.

Bratislavsky kraj, Beznieko, outside Laksarksa Nova Ves, Quercus pubescens, 25.X.2014, Larsson 313-14* (GB, TUR-A). SLOVENIA. Pregarje, Fagus, 8.VI.2014, Ferisin 14-13* (GB). SPAIN. Biscaye. Bermeo, sur le mont Sollube, in plantation Pinus radiatae, 13.XII.2003 Fernández Sasia et al. 031213-03 (holotype, private herb. of R.F.S., GenBank acc. no. KJ938768). SWEDEN. Bohuslän, Uddevalla, Kuröds skalgrusbankar, Corylus avellana, 2.X.2004, Larsson 129-04* (GB); Halland, Fjärås, Tjolöholm, Quercus robur, 28.X.1984.
Jacobsson 84178* (GB); Skipås, Stensjöstrand, Quercus robur, Fagus sylvatica, 17.VIII.2009, Larsson 202-09* (GB).

\section{Ecology, distribution and phenology}

Inocybe caprimulgi seems to be associated and forming mycorrhiza with Pinus sylvestris and Betula on dry sandy soils. It can share the site with several other species of Inocybe, e.g., I. lacera (Fr.: Fr.) P. Kumm., I. jacobi Kühner, I. sam- 

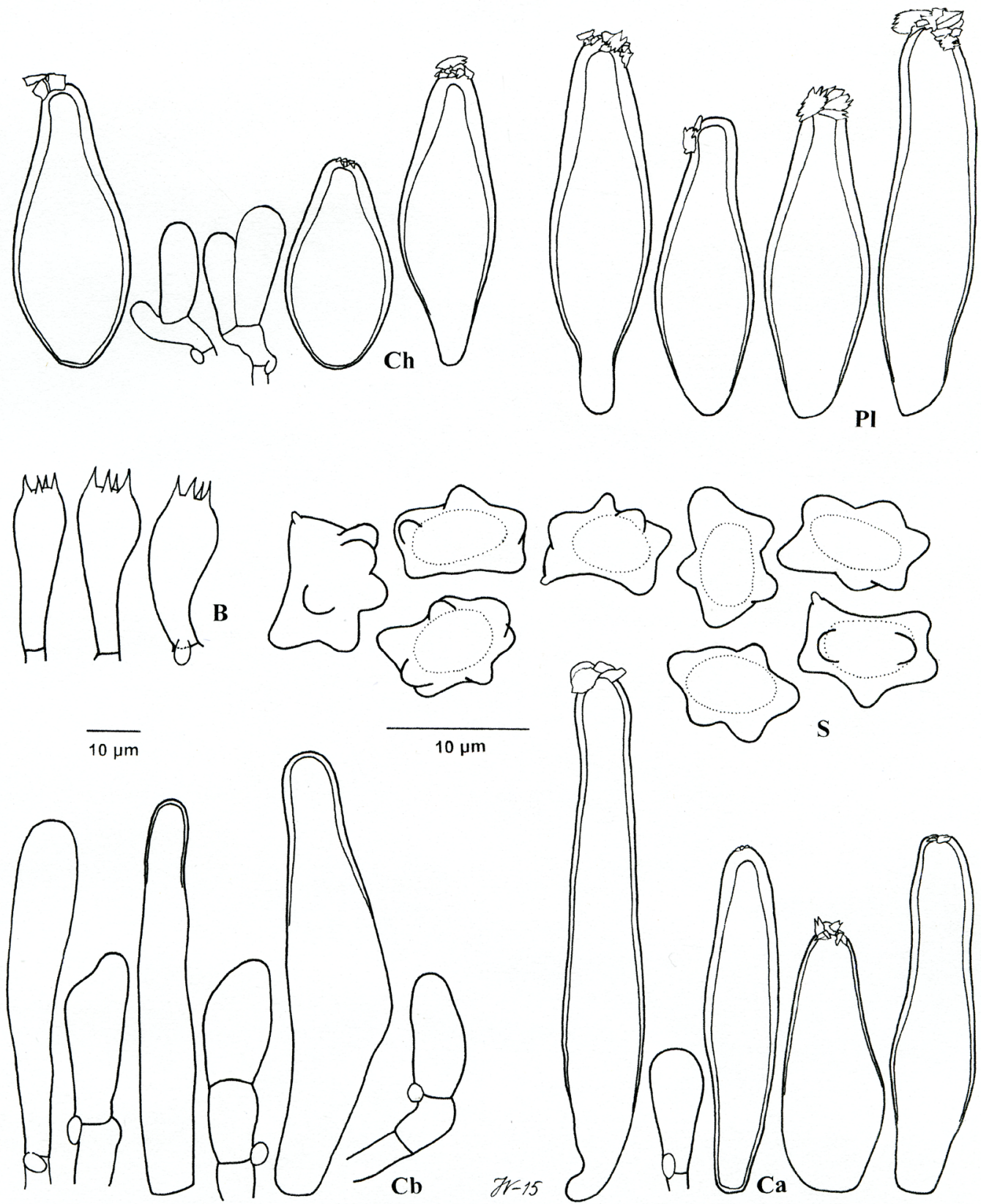

Fig. 7. Microscopical characters of Inocybe caprimulgi (holotype). $\mathrm{B}=$ basidia, $\mathrm{Ca}=$ caulocystidia and paracystidia at stipe apex, $\mathrm{Cb}=$ caulocystidia and paracystidia at stipe base, $\mathrm{Ch}=$ cheilocystidia and paracystidia, $\mathrm{Pl}=$ pleurocystidia, $\mathrm{S}=$ spores. 
bucina (Fr.: Fr.) Quél, I. ochroalba Bruyl. and I. ericetorum Vauras \& Kokkonen. The sites with I. caprimulgi have been often fine brown sand, and the species is growing mostly on bare sand. The soils of such localities can easily be taken as quite acid. However, the range of $\mathrm{pH}$-values of the surface soils from the growing sites analysed, including the type locality, were 5.4-6.15$6.8(\mathrm{n}=6)$. There are mostly some Betula trees or at least saplings in the Nordic pine forests. But there exist several collections of the species without Betula neaerby, according to the labels. On the other hand, we have found I. caprimulgi in low-alpine localities with Betula nana.

I. caprimulgi has a wide distribution range in the Nordic countries (Fig. 8), from hemiboreal to northern boreal zone, reaching the alpine heaths of Betula nana. It is more common in northern part of the area, maybe because of the abundant sandy areas there. The species has a long period of basidiomata production, from mid-July to late September, reaching a peak between mid-August to mid-September.

\section{Discussion}

In the boreal zone of Finland Inocybe caprimulgi is the most characteristic nodulose-spored species of the section Marginatae in sandy areas. A quite similar species, both in macroscopical and microscopical characters and habitat on sandy areas, but with a more southern distribution, is I. krieglsteineri Fernández Sas. It was described from Northern Spain (Fernández Sasia 2004), but was reported already earlier from Germany and the Netherlands under the names I. mixtiloides and I. mixtilioides (Krieglsteiner 1989). This species is about the same size as I. caprimulgi, and both species can also become blackish when dried. It has a pileus with ochre-yellow colour, at centre ochre-brown, being more yellow than I. caprimulgi. However, the yellow colour can disappear in dry weather. Comparing the microscopical characters, the spores are quite similar, but on average slightly larger in I. krieglsteineri. There are more dissimilarities in the cystidia. $I$. caprimulgi is characterized by having cystidia that are somewhat broader, and very often with a rounded base. I. krieglsteineri has on average longer and narrower lageniform pleurocystidia and longer caulocystidia. Ecologically, I. kriegl- steineri seems to grow mainly with Quercus (Krieglsteiner 1989), but Esteve-Raventos et al. (2015) mention also collections with Pinus pinea, . pinaster and Castanea sativa. We have seen collections of the species from France, Germany, Slovakia, Slovenia and from the coast of Southern Sweden, where it seems to grow on calcareous sandy soil near Quercus robur and Corylus avellana. Stangl (1989: 282-283, Plate 35.4) describes an Inocybe sp., collected in Bayern near Betula, Pinus and Picea abies. This can be I. krieglsteineri or I. caprimulgi, but we have not studied this specimen.

The microscopical characters of I. krieglsteineri given by Krieglsteiner (1989) are: spores 7.8-9.5(-10.3) × (5.7-)6.0-7.4(-7.8) $\mu \mathrm{m}$, cystidia of hymenium (53-)58-92 $\times 11-19 \mu \mathrm{m}$, caulocystidia often over $100 \mu \mathrm{m}$ long, 10-18 $\mu \mathrm{m}$ wide. Our notes from 5 collections, including the holotype, are: Spores (7.9-)8.2-9.5$10.8(-11.5) \times(5.8-) 6.2-7.0-7.9(-9.1) \mu \mathrm{m}$, range of mean values $9.4-9.6 \times 6.8-7.3 \mu \mathrm{m}, \mathrm{Q}=$ (1.15-)1.2-1.36-1.45(-1.55), range of mean Q -values 1.32-1.40 $(\mathrm{n}=80)$. Basidia $24-32-37 \times$ 10-11-12 $\mu \mathrm{m}$, clavate, 4-spored $(\mathrm{n}=8)$. Pleurocystidia 55-71-84(-85) × (13-)14-17-23(-24) $\mu \mathrm{m}(\mathrm{n}=41)$, mainly lageniform, with up to 3 $\mu \mathrm{m}$ thick, pale yellow to yellow wall, often with abundant crystals, part of these small, below the larger ones. Cheilocystidia 39-55-72 × 12-16$17 \mu \mathrm{m}(\mathrm{n}=23)$, fairly similar to pleurocystidia but more variable, often with rounded base and yellow-brown contents; paracystidia moderately abandant, clavate, pyriform to oval, 11-20-27 $\times$ 5-9-15 $\mu \mathrm{m}(\mathrm{n}=13)$. Caulocystidia descending to base of stipe, at apex (38-)57-76-104 $\times$ $(12-) 14-18-26(-28) \mu \mathrm{m}(\mathrm{n}=49)$, fairly similar to cheilo- and pleurocystidia but more variable, often with long neck and yellow-brown contents; cauloparacystidia at stipe apex clavate, oval or pyriform, 15-21-31 × 8-11-16 $\mu \mathrm{m},(\mathrm{n}=27)$.

In the phylogenetic analyses $I$. caprimulgi comes out as a sister species to I. substellata Kühner with high support values $(88 \%, 1.0)$, indicating that they are closely related (Fig. 1). The sequence difference in the ITS region between the two species is 23 substitutions and 11 insertion/ deletion events. The large sequence difference support the recognition of $I$. caprimulgi as a distinct species. I. substellata differs clearly from $I$. caprimulgi both in macro- and micromorphology and in the ecology by being an alpine species. $I$. 


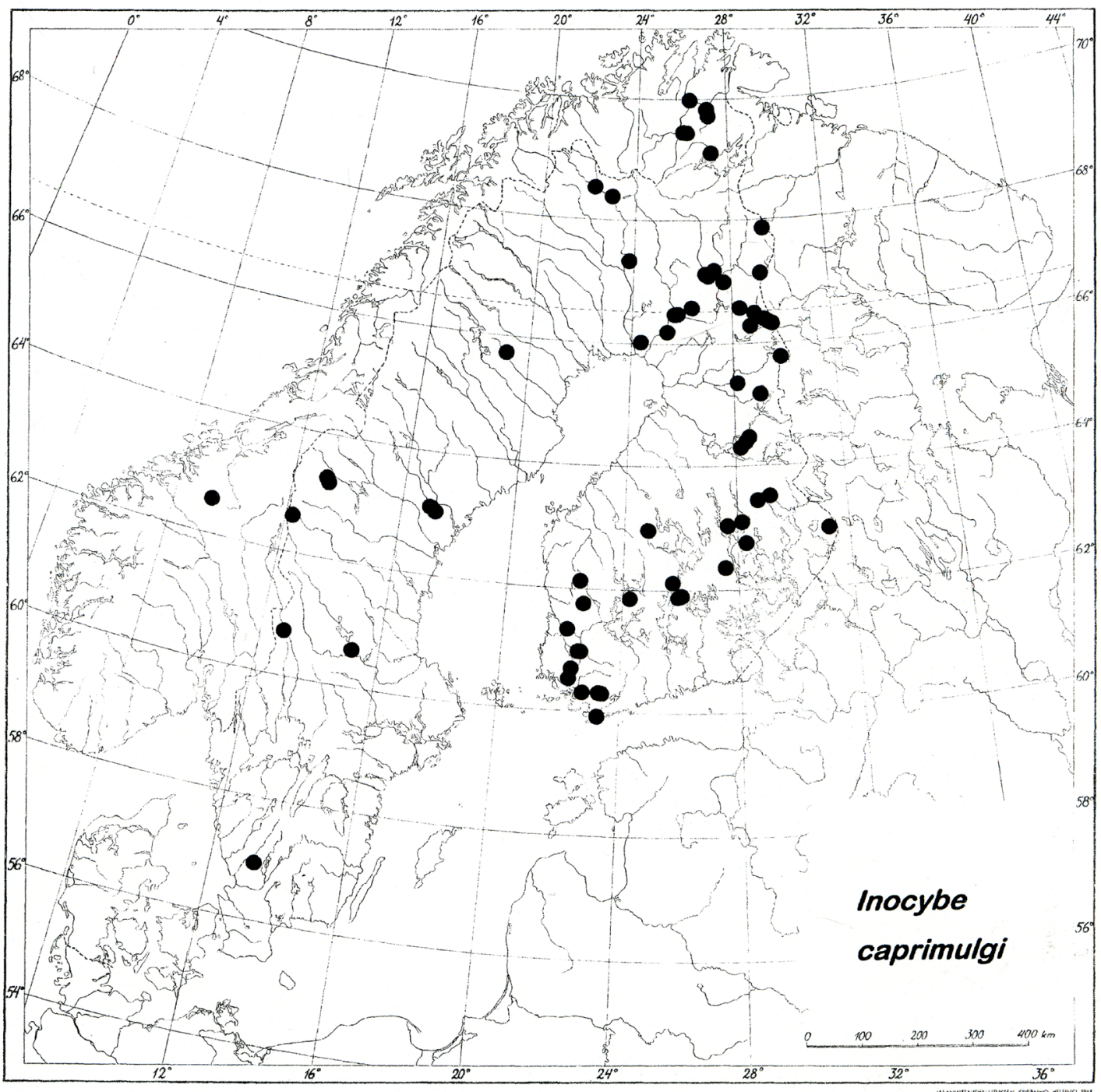

Fig. 8. Distribution of Inocybe caprimulgi in the Nordic countries according to the specimens examined.

mixtilis (Britzelm.) Sacc., a very common species in the Nordic countries, can sometimes share the habitat with I. caprimulgi, but it differs by having a more even and brighter pileus, white stipe, spores with more nodules and shorter cystidia.

Inocybe substellata Kühner, Docum. Mycol. 19, 74: 25 (1988) - Figs. 4, 6c, 9

Typus: France. Savoie. Région de Pralognan, Haute vallée de Champagny, Parc de la Vanoise, parmi les Salicibus herbaceis et Polytrichis nor-
vegicis,15.XIII.1973 Kühner 73-218* (G, holotypus, examined). GenBank No. KT958928.

Description of our Nordic material. Pileus 0.6$2.6 \mathrm{~cm}$ in diam, conico-convex to convex, slightly umbonate, grey-brown to pale brown, often with abundant whitish velipellis. Lamellae up to $5.5 \mathrm{~mm}$ wide, subventricose to ventricose, narrowly adnate, first whitish, pale grey, then yellowish grey-brown. Stipe $1.4-2.5 \times 0.2-0.6 \mathrm{~cm}$, mostly equal, base subbulbous to marginately bulbous, bulb up to $6 \mathrm{~mm}$ wide; first whitish, lat- 
er yellowish, totally white-pruinose, longitudinally striate. Smell indistinct. Spores (9.8-)10.0 11.2-12.2(-12.8) × (7.5-)7.7-8.7-10.3(-11.1) $\mu \mathrm{m}$, range of mean values $11.1-11.3 \times 8.2-8.9$ $\mu \mathrm{m}, \mathrm{Q}=(1.05-) 1.1-1.29-1.5(-1.55)$, range of mean Q -values $1.26-1.36(\mathrm{n}=60$, from 2 collections); with 7-10 rather prominent, rounded nodules, rather dark yellow brown. Basidia $31-$ $38-43 \times 10-12-15 \mu \mathrm{m}$, clavate, 4-spored $(\mathrm{n}=22$, from 2 collections). Pleurocystidia 64-76-92 $\times$ 15-19-22 $\mu \mathrm{m}(\mathrm{n}=21$, from 2 collections), subfusiform to sublageniform, with up to $3.5 \mu \mathrm{m}$ thick, pale yellow to yellow wall, with abundant crystals. Cheilocystidia (46-)57-73-90(-93) $\times$ (12-)14-18-22 $\mu \mathrm{m}(\mathrm{n}=19$, from 2 collections), abundant, fairly similar to pleurocystidia but more variable, some with brownish contents and some with rounded base; paracystidia clavate to oval, $17-23-28 \times 7-9-10 \mu \mathrm{m}(\mathrm{n}=14$, from 2 collections). Caulocystidia descending to base of stipe, at apex 61-81-110 × 15-19-22 $\mu \mathrm{m}(\mathrm{n}=$ 7 , from 2 collections), cauloparacystidia at stipe apex clavate, oval or pyriform, 22-29-36 $\times 7-8$ $9 \mu \mathrm{m},(\mathrm{n}=3$, from 1 collection).

Examination of holotype: Spores (9.7-)10.2$11.7-12.9 \times(7.7-) 7.8-8.6-12.9 \mu \mathrm{m}, \mathrm{Q}=(1.15$ )1.2-1.36-1.6 $(\mathrm{n}=20$. Basidia 30-31 $\times 14-15$ $\mu \mathrm{m}$, clavate, 4-spored $(\mathrm{n}=2)$. Pleurocystidia 45-56-66 × 17-21-24 $\mu \mathrm{m}(\mathrm{n}=14)$, subutrtiform to broadly fusiform, often with crystals, with up to $3 \mu \mathrm{m}$ thick, fairly yellow wall. Caulocystidia at apex 50-59-70 × 19-22-23 $\mu \mathrm{m}(\mathrm{n}=3)$, fairly similar to pleurocystidia but more variable, cauloparacystidia at stipe apex $21-45 \times 8-13 \mu \mathrm{m}$, $(\mathrm{n}=2)$.

Additional specimens examined: FINLAND. Enontekiön Lappi. Enontekiö, Kilpisjärvi, Malla Strict Nature Reserve, Pikku-Malla, 11.VIII.1986 Vauras 2223F* (TUR-A, GB). NORWAY. Troms. Storfjord, near Bossovarri at the border of Finland, 21.VIII.1014 Vauras $30672 F^{*}$ (TUR-A, GB). SWEDEN. Torne lappmark, Jukkasjärvi, Abisko, Latnjavagge, 17.VIII.2013 Larsson 52-13* (GB), 21.VIII.2013 Larsson 167-13* (GB).

\section{Ecology, distribution and phenology}

Inocybe substellata seems to be a species with preferences for the alpine zone, forming mycorrhizal associations with both dwarf Salices and
Salix bushes. According to our collections it favours margins of dried ponds, as well as alpine heaths with $S$. herbacea. So far, we have only a few collections from Fennoscandia, all collected in August.

\section{Discussion}

Our material of I. substellata fits well to the original description by Kühner (1988), who found the species growing with Salix herbacea. However, in the description he does not mention the occurrence of a velipellis, which is rather abundant in some of our specimens. In the arctic and alpine zones the velipellis often appears as strong, even if the species have no or much less velipellis in more southern areas. Kühner (1988) gives cystidia walls as colourless, but we found them pale yellow to yellow. Fruit bodies having velipellis can somewhat resemble I. argenteolutea Vauras, but this species has brighter yellow lamellae and stipe, and spores quite similar as I. grammata Quél. I. substellata has been recorded also from Austria (Bandini http://www.inocybe.org/untergattung-inocybe-h\%C3\%B6ckersporer/substellata/) and Turkey (Solak et al. 2009).

Inocybe lacunarum Vauras \& E. Larss., sp. nova $\quad-$ Figs. 5, 6d-e, 10-11

\section{MycoBank no.: MB 815079}

Diagnosis: Fairly small and gracile species with stipe totally pruinose and stellate spores, measuring (9.5-)10.1-12.7(-13.8) × (8.0-)8.1$10.3(-11.1) \mu \mathrm{m}$, closely related and resembling fairly much $I$. populea and I. salicis, but differing from these both in micro-morphology and ITS sequence data. In hemiboreal to southern boreal zones, with habitat mainly on moist clayey soils, with deciduous trees.

Typus: Finland. Varsinais-Suomi. Turku, Ruissalo island, ca $100 \mathrm{~m} \mathrm{~N}$ of Honkapirtti, by the road to the villa Turila, W side of the road, deciduous forest with Quercus robur, Corylus avellana, Betula pendula, Salix caprea, Populus tremula and Acer platanoides, moist depression, with Inocybe curvipes, I. flavella coll. and Hydnotrya tulasnei. alt. ca $6 \mathrm{~m}$., grid $27^{\circ} \mathrm{E}$ : 

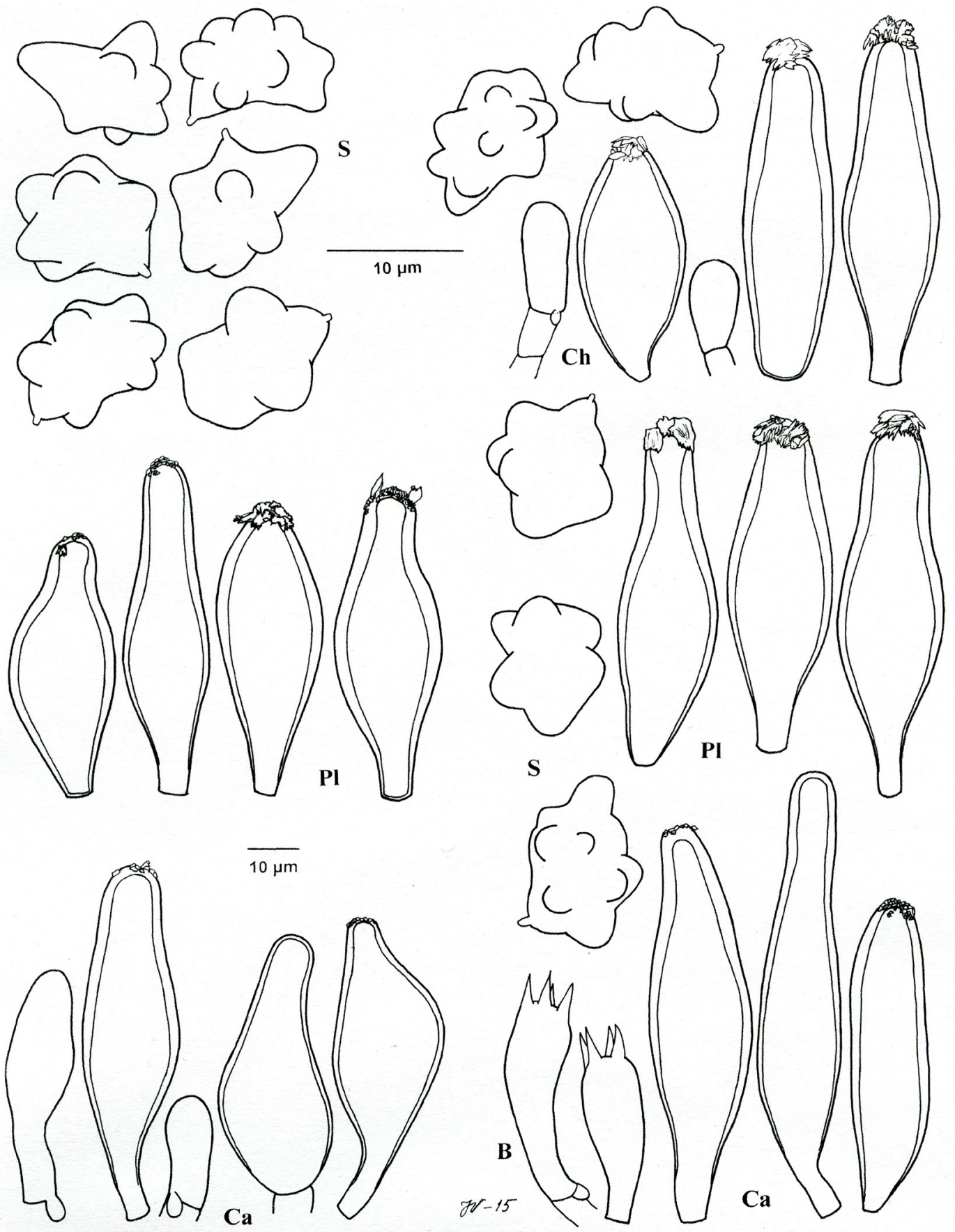

Fig. 9. Microscopical characters of Inocybe substellata (from holotype on the left, from Vauras $2223 \mathrm{~F}$ on the right). For symbols, see Fig. 7. 
671190:323298, 5.VIII.1997 Vauras 12244F (TUR-A 171771 - holotypus; GB, H - isotypi, GenBank No. KT958908).

Etymology: lacunarum refers to the typical growing site in moist depressions, being at times under water.

Pileus $0.6-4.0 \mathrm{~cm}$ in diam, paraboloid to campanulate, finally applanate to plano-concave, umbo broad and round, yellow-brown around disc $(60 \mathrm{M})$, outwards paler, ochraceous yellow to dirty yellow-brown (65P), smooth and sometimes with velipellis around centre, outwards radially rimulose to rimose. Lamellae moderately crowded, to $3 \mathrm{~mm}$ wide, subventricose, narrowly adnate to free, pale grey, brownish grey (S30Y30M10, 90L), then grey-brown; edge pale. Stipe $1.5-5.3 \times 0.2-0.5 \mathrm{~cm}$, equal, base subbulbous to marginately bulbous, bulb 5-7 mm wide; first white, with yellow-brown tint at stipe base, later slightly yellowish to yellow-brown, totally white-pruinose, longitudinally striate. Context whitish in pileus and stipe when young, later partly pale yellow-brown in stipe. Smell weak. Color of exsiccatae: pileus fairly pale brown, lamellae brown, stipe brown to dark brown, rarely blackish brown, flesh brown, but in pileus and bulb pale. Spores (9.5-)10.1-11.4-12.7(-13.8) $\times(8.0-) 8.1-9.1-10.3(-11.1) \mu \mathrm{m}$, range of mean values $11.0-11.8 \times 8.6-9.5 \mu \mathrm{m}, \mathrm{Q}=(1.1-) 1.15$ 1.26-1.4(-1.5), range of mean $\mathrm{Q}$-values 1.22 $1.28(\mathrm{n}=140$, from 7 collections $)$; stellate, with about 14-16 prominent, narrowly conical and rounded nodules, apical nodule often largest, to $3.5 \mu \mathrm{m}$ long; yellow-brown. Basidia 26-32$38(-40) \times(9-) 10-11-13(-15) \mu \mathrm{m}(\mathrm{n}=51$, from 7 collections), clavate, 4 -spored. Pleurocystidia $(54-) 57-67-80(-84) \times 14-20-25(-30) \mu \mathrm{m}(\mathrm{n}=$ 56 , from 8 collections), ventricose, utriform to fusiform, some with pedicel, thick-walled, with up to $5 \mu \mathrm{m}$ thick, pale yellowish wall, usually with crystals; frequent. Cheilocystidia fairly similar to pleurocystidia but on average shorter, narrower and more variable, 38-55-76 $\times$ 13-18-21 $\mu \mathrm{m}(\mathrm{n}=24$, from 2 collections), some with yellowish contents, some with rounded base; paracystidia abundant, ovoid, pyriform to clavate, $14-19-28 \times 7-11-16 \mu \mathrm{m}(\mathrm{n}=34$, from 2 collections). Caulocystidia descending to base of stipe, at stipe apex fairly similar to cheiloand pleurocystidia but more variable, often with rounded base, 40-62-80 × 13-19-21 $\mu \mathrm{m}(\mathrm{n}=14$, from 2 collections); cauloparacystidia at stipe apex pyriform to clavatae, $12-23-34 \times 8-12-15$ $\mu \mathrm{m}(\mathrm{n}=19$, from 2 collections), abundant.

Specimens examined: FINLAND. VarsinaisSuomi. Kaarina, Rauhalinna, 30.VIII.2006 Kokkonen \& Vauras 23975 (TUR-A, GB). Parainen, Kirjala, Trollgärda, 11.VIII.2000 Vauras 16472 (TUR-A); Lenholm, 22.VII.1981 Vauras 971 \& Huhtinen (TUR-A). Salo, park of Railway Station, 9.VII.2002 Vauras 18823 (TUR); Halikko, Vuorelanmäki, 30.VIII.2014 Vauras 30732 (TUR-A). Taivassalo, Orikvuori, 26.VII.2000 Vauras 16178 (TUR-A). Turku, Iso-Pukki, 2.VIII.2007 Kokkonen \& Vauras 25023 (TURA, GB); Ispoinen, 5.IX.1992 Vauras 7217 (TUR-A); Katariinanlaakso, 20.VII.1981 Vauras 940 (TUR-A); Muhkurinmäki, 9.VIII.1993 Vauras 8105F* (TUR, GB), 21.VIII.1998 Vauras 14050 (TUR-A); Ruissalo (altogether 7 localities), 26.VII.1980 Huhtinen \& Vauras (TUR), 5.VIII.1997 Vauras 12234 (TUR-A), $12244 F^{*}$ (holotype, isotypes), 7.VIII.1997 Vauras 12284, 12285 (TUR-A), 11.VIII.1997 Vauras 12298, 12300 (TUR-A), 20.VIII.1997 Vauras 12398, 12399 (TUR-A), 22.VIII.1997 Vauras 12416 (TUR-A), 21.VIII.1998 Vauras 14056 (TUR-A, O), 22.IX.2001 Vauras $17978 F$ (TUR-A), 25.VIII.2006 Vauras 23963 (TUR-A), 28.VIII.2006 Vauras 23964 (TUR-A), 7.IX.2006 Kokkonen \& Vauras 24046 (TUR-A), 30.VII.2007 Kokkonen \& Vauras 24874 (TURA), 1.VIII.2007 Kokkonen 65/07b, 68/07 (TUR); Satava, Höyttinen, 20.VIII.2006 Winqvist (TURA); Uittamo, 20.VII.1981 Vauras $946 F$ (TUR, TUR-A), 6.VIII.1989 Vauras 3490F (TUR-A), 1.IX.1992 Vauras 7093 (TUR-A), 22.VIII.1993 Vauras 8208 (TUR-A), 5.IX.1993 Vauras 8605 (TUR-A). Uusimaa. Helsinki, Annala, 15.VII.1978 Saarenoksa (H), 9.VIII.1978 Saarenoksa $05278(\mathrm{H})$; Herttoniemi, 8.VIII.1993 Kytövuori 93-061 (H). Vantaa, Kulomäki Asola, 12.VIII.2008 Toivonen 8008 (TUR-A); Maantiekylä, Kylmäojan korpi, 8.IX.2008 Toivonen 8086 (TUR). Etelä-Häme. Tampere, Peltolammi, 21.VIII.1993 Söderholm 2128 (TUR). Urjala, Raikko, 22.VIII.2003 Vauras 20151* (TUR-A, GB). Valkeakoski, Sääksmäki, Rauttunniemi, 23.VIII.1992 Kosonen (TUR-A). SWEDEN. Uppland. Stockholm, Artilleriparken, 14.VIII.1895 Romell (S). 

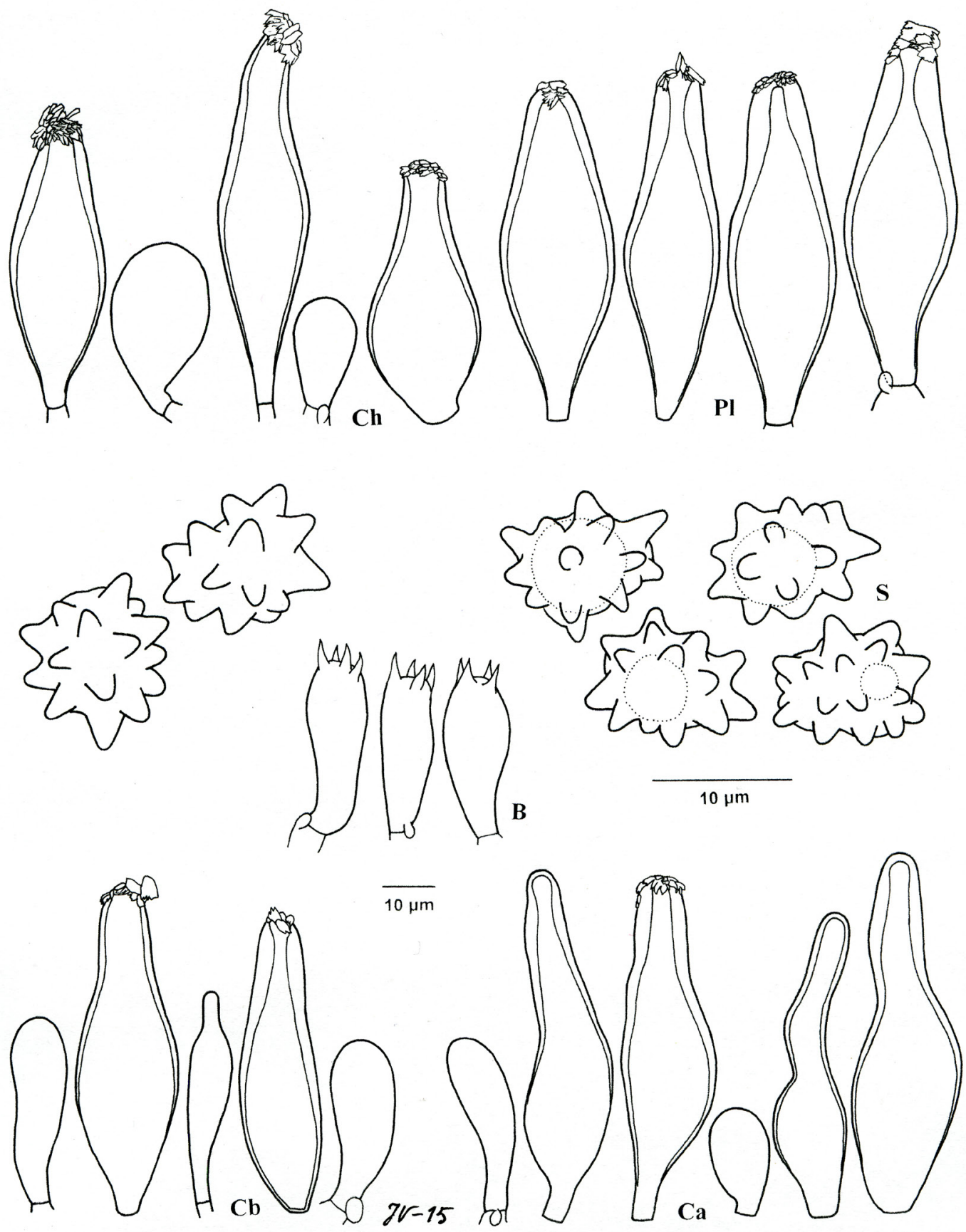

Fig. 10. Microscopical characters of Inocybe lacunarum (holotype). For symbols, see Fig. 7. 


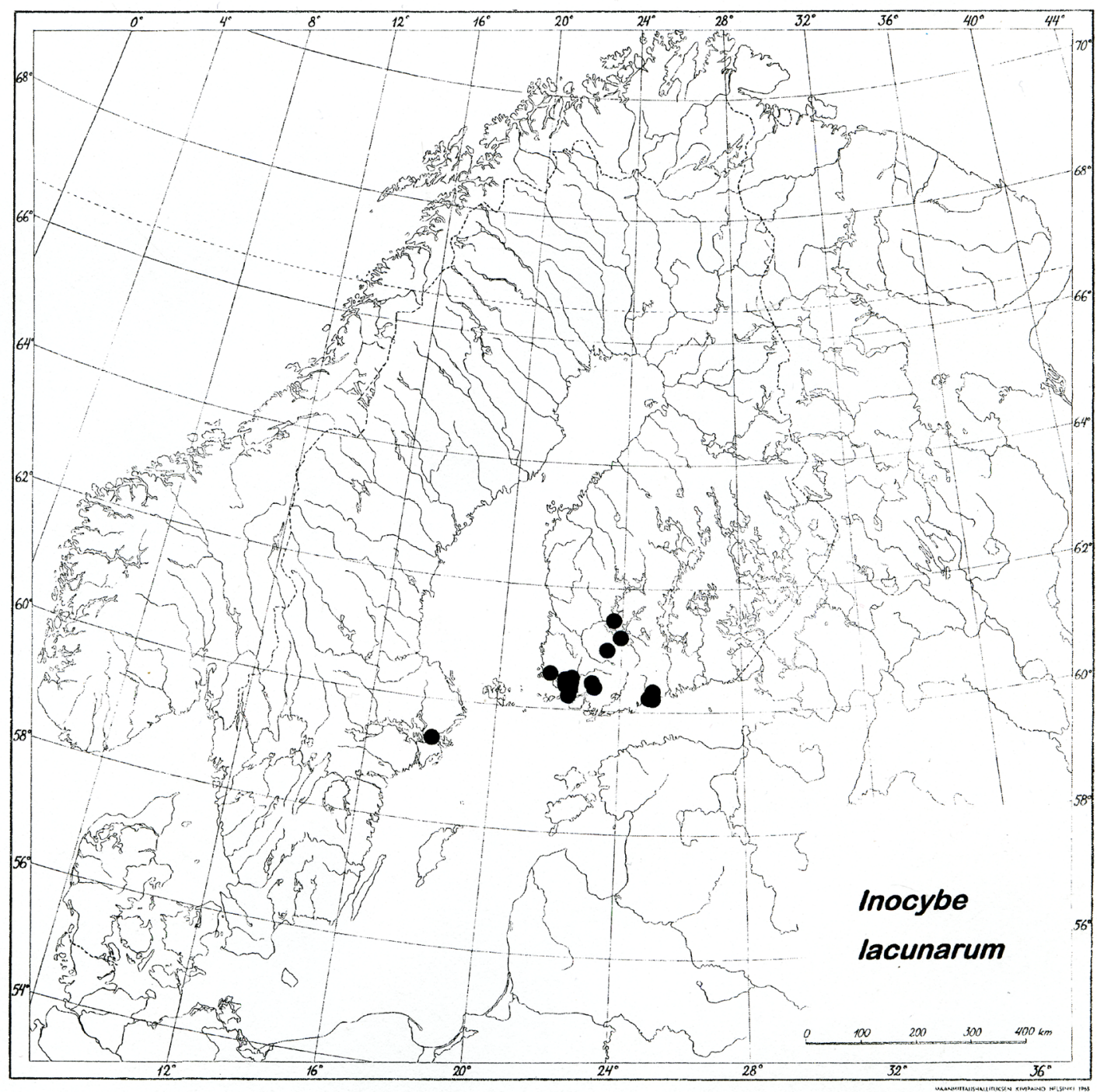

Fig. 11. Distribution of Inocybe lacunarum in the Nordic countries according to the specimens examined.

\section{Ecology, distribution and phenology}

Inocybe lacunarum seems to be restricted to deciduous forests, and is likely to be associated and forming mycorrhiza with Betula pendula, Populus tremula and Quercus robur. A typical growth site is bare soil in moist depressions or ditches. Other sites have been in moist shore forest, park, on lawn, pasture, field margin, on forest track and on path. The soil is mostly clay. Many localities are nature reserves with many rare species. However, the range of $\mathrm{pH}$-values of the surface soils analysed, 4.8-4.9 $(\mathrm{n}=2)$, is quite acid.
I. lacunarum seems to have a restricted distribution range in hemiboreal and southern boreal zones in SW Finland and Stockholm in Sweden. Many of the collections are from Turku, from Ruissalo island. The species has a long period of forming basidiomata, from early July to late September, reaching a peak in August. 


\section{Discussion}

Inocybe lacunarum is a rather characteristic species with its stellate spores. In the phylogenetical tree (Fig. 1) it comes out as a sister species to I. populea, described from Japan (Kobayashi $\&$ Courtecuisse 2000). According to the original description it is about the same size, and with rather similar structure and colour. However, in micro-morphology it is somewhat different. The spores are smaller, 8.0-13.5 × 6.5-11.0 $\mu \mathrm{m}$, on average $9.3-11.3 \times 7.5-9.4 \mu \mathrm{m}$ and $\mathrm{Q}$ $=1.1-1.3$. Furthermore, the nodules are not as regular as in I. lacunarum, but there are also some crown-shaped double nodules. Pleurocystidia are shorter and narrower, 34-60(-71) $\times$ $12-15(-19) \mu \mathrm{m}$, as also the caulocystidia at stipe apex, which are $28-48 \times 12-17 \mu \mathrm{m}$. In addition, according to the drawings, there are no crystals on the cystidia (Kobayashi \& Courtecuisse 2000, Kobayshi 2002). Our measurements from a paratype (TAKK 1565-5, TUR-A, GenBank acc. no. KT958911), collected in the type locality in Japan, Shiga, Otsu, under Populus nigra, fits rather well with the original description: spores (9.1)9.3-9.9-11.0 × (7.1-)7.3-8.2-8.8(-8.9) $\mu \mathrm{m}, \mathrm{Q}$ $=1.1-1.21-1.35,(\mathrm{n}=20)$; basidia $22-27-35 \times$ 9-12-16 $\mu \mathrm{m}(\mathrm{n}=13)$; pleurocystidia 41-46-55 $\times 10-15-16 \mu \mathrm{m}(\mathrm{n}=10)$; caulocystidia at stipe apex 23-46-53 × 15-18-21 $\mu \mathrm{m}(\mathrm{n}=10)$.

Our phylogenetic analyses confirm what was stated already by Kobayashi \& Courtecuisse (2000), that I. populea is related to I. salicis (Fig. 1). Inocybe lacunarum and I. populea form a strongly supported clade $(80 \%, 1.0)$, suggesting a close relationship. The sequence difference in the ITS region is 31 substitutions and 12 insertion/deletion events, supporting the recognition of I. lacunarum as a distinct species from $I$. populea.

I. salicis differs microscopically clearly from I. lacunarum and I. populea by having only short nodules on the spores. I. calospora Quél. also has stellate spores, but with 20-30 cylindric, blunt spines.
Acknowledgements: Curators of herbaria G, H and OULU are gratefully acknowledged for arranging loans, and Roberto Fernández Sasia, Takahito Kobayashi, Thomas Kuyper, Ditte Bandini, Ilkka Kytövuori, Esteri Ohenoja, Stig Jacobsson, Katri Kokkonen, Reima Saarenoksa, Mika Toivonen, Enrico Bizio, and other friends for allowing us to study their collections. Financial support was received from The Swedish Taxonomy Initiative, ArtDatabanken SLU Uppsala.

\section{References}

Bandini, D. 2015: http://www.inocybe.org. Accessed 5 Nov 2015.

Cailleux, A. 1981: Code des couleurs des soils. - Boubée.

Cripps, C., Larsson, E. \& Horak, E. 2010: Subgenus Mallocybe (Inocybe) in the Rocky Mountain alpine zone with molecular reference to European arctic-alpine material. - North American Fungi. 5: 97- 126.

Drummond, A.J., Suchard, M.A., Xie, D. \& Rambaut, A. 2012: Bayesian Phylogenetics with BEAUti and the BEAST 1.7. - Molecular Biology and Evolution 29:1969- 1973 .

Esteve-Raventós, F., Moreno, G., Bizio, E. \& Alvarado, P. 2015: Inocybe flavobrunnescens, a new species in section Marginatae. - Mycological Progress 14:14, DOI: $10.1007 / \mathrm{s} 11557-015-1036-0$.

Fernández Sasia, R. 2004: Inocybe krieglsteineri sp. nov., une espèce encore peu connue. - Bulletin de la Société Mycologique de France 120: 179-186.

Gardes, M. \& Bruns, T.D. 1993: ITS primers with enhanced specificity for basidiomycetes -application to the identification of mycorrhizas and rusts. - Molecular Ecology 2: 113-118.

Holmgren, P.K., Holmgren, N.H. \& Barnett, L.C. 1990: Index herbariorum 1. The herbaria of the world, 8th ed. - Regnum Vegetabile 120: 1-693.

Hopple, J.S. Jr. \& Vilgalys, R. 1999: Phylogenetic relationships in the mushroom genus Coprinus and dark spored allies based on sequence data from the nuclear gene coding for the large ribosomal subunit RNA: divergent domains, outgroups, and monophyly. - Molecular Phylogenetics and Evolution 13: 1-19.

Katoh, K. \& Standley, D.M. 2013: MAFFT multiple sequence alignment software version 7: improvements in performance and usability. - Molecular Biology and Evolution 30: 772-780.

Kobayashi, T. 2002: The taxonomic studies on the genus Inocybe. - Nova Hedwigia Beiheft 124: 1-246.

Kobayashi, T. \& Courtecuisse, R. 2000: Two new species of Inocybe, section Marginatae (Agaricales, Cortinariaceae) from Japan. - Mycoscience 41: 161-166.

Kokkonen, K. \& Vauras, J. 2012: Eleven new boreal species of Inocybe with nodulose spores. - Mycological Progress 11: 299-341.

Krieglsteiner, G.J. 1989: Über neue, Seltene, kritische Makromyzeten in der BR Deutschland (Mitteleuropa) 11. - Beiträge zur Kenntnis der Pilze Mitteleuropas 5: 115-140.

Kühner, R. 1933: Notes sur le genre Inocybe: 1) Les Inocybes goniosporés (Fin). - Bulletin de la Société Mycologique de France 49: 81-121. 
Kühner, R. 1988: Diagnoses de quelques nouveaux Inocybes récoltés en zone alpine de la Vanoise (Alpes françaises). - Documents Mycologiques 19(74): 1-27.

Küppers, H. 1981: DuMont's Farrben-Atlas. 2nd ed. 163 pp. DuMont Buchverlag, Köln.

Kõljalg, U., Nilsson, R.H., Abarenkov, K., Tedersoo, L., Taylor A.F.S., Bahram, M., Bates, S.B., Bruns, T.D., Bengtsson-Palme, J., Callaghan, T.M., Douglas, B., Drenkhan, T., Eberhardt, U., Dueñas, M., Griffith, T.G.W., Hartmann, M., Kirk, P.M., Kohout, P., Larsson, E., Lindahl, B.D., Lücking, R., Martín, R.M.P., Matheny, P.B., Nguen, N.H., Niskanen, T., Oja, J., Peay, K.G., Peintner, U., Peterson, M., Põldmaa, K., Saag, L., Saar, I., Schüssler, A., Scott, J.A., Senés, C., Smith, M.E., Suija, A., Taylor, D.L., Telleria, T., Weiss, M. \& Larsson, K.-H. 2013: Towards a unified paradigm for sequence-based identification of fungi. - Molecular Ecology 22: 5271-5277, DOI: 10.1111/ mec. 12481 .

Larsson, E. \& Jacobsson, S. 2004: The controversy over Hygrophorus cossus settled using ITS sequence data from 200-year-old type material. - Mycological Research 108: 781-786.

Larsson., E., Vauras, J. \& Cripps, C. L. 2014: Inocybe leiocephala, a species with an intercontinental distribution range - disentangling the I. leiocephala - subbrunnea - catalaunica morphological species complex. - Karstenia 54: 15-39.

Larsson, E. \& Örstadius, L. 2008: Fourteen coprophilous species of Psathyrella identified in the Nordic countries using morphology and nuclear rDNA sequence data. - Mycological Research 112: 1165-185.
Nylander, J. A. A. 2004: MrModeltest v2. - Program distributed by the author.

Ronquist, F. \& Huelsenbeck, J.P. 2003: MrBayes 3, Bayesian phylogenetic inference under mixed models. - Bioinformatics 19:1572-1574.

Ryberg, M., Larsson, E. \& Jacobsson, S. 2010: An evolutionary perspective on morphology and ecological characters in the mushroom family Inocybaceae (Agaricomycotina, Fungi). - Molecular Phylogenetics and Evolution 55: 431-442.

Solak, M.H., Alli, H., Işiloğlu, M. \& Kalmiş, E. 2009: Some new records of Inocybe (Fr.) Fr. from Turkey. Turkish Journal of Botany 33: 65-69.

Stangl, J. 1989: Die Gattung Inocybe in Bayern. - Hoppea 46: 5-388.

Swofford, D.L. 2003: PAUP*. Phylogenetic Analysis Using Parsimony (* and Other Methods). Version 4. Sinauer Associates. Sunderland, Massachusetts.

Vauras, J. \& Kokkonen, K. 2009: Finnish records on the genus Inocybe. The new species Inocybe saliceticola. - Karstenia 48: 57-67.

White, T.J., Bruns, T., Lee, L. \& Taylor, J.W. 1990: Amplification and direct sequencing of fungal ribosomal RNA genes for phylogenetics. In: Innis, M.A., Gelfand, D.H., Sininski, J.J. \& White, T.J. (eds.): PCR protocols, a guide to methods and applications: $315-$ 322. Academic Press. New York. 